\title{
Kasus UPS, Polda Metro Periksa Mantan Kepala Dinas Pendidikan DKI
}

\author{
TUGAS 2
}

\author{
TUTORIAL ONLINE (TUTON) \\ MPDR 5301.04 KEPEMIMPINAN DAN MANAJEMEN \\ PENDIDIKAN DASAR \\ MASA REGISTRASI 2019.2
}

RISDENI HUTAGALUNG

NIM : 530018997

\author{
PROGRAM PASCASARJANA \\ UNIVERSITAS TERBUKA \\ 2019
}


Kasus UPS, Polda Metro Periksa Mantan Kepala Dinas Pendidikan DKI

Metrotvnews.com, Jakarta: Polda Metro Jaya memeriksa mantan Kepala Dinas Pendidikan DKI Jakarta

Lasro Marbun. Pemeriksaan ini terkait kasus dugaan penyelewengan dana pengadaan alat uninterruptible power supply (UPS) pada APBD DKI 2014 di sekolah-sekolah wilayah Jakarta:

Lasro yang kini menjabat Kepala Inspektorat DKI Jakarta itu diperiksa oleh penyidik Subdit Tipikor Ditreskrimsus Polda Metro Jaya sebagai saksi dugaan korupsi pengadaan UPS saat ia masih menjabat sebagai Kepala Dinas Pendidikan DKI Jakarta.

"Saat ini ia masih diperiksa penyidik. Itu kaitannya dengan dia sebagai Kadisdik sewaktu pengadaan UPS," kata Kabid Humas Polda Metro Jaya Komisaris Besar Martinus Sitompul di Mapolda Metro Jaya, Rabu (11/3/2015).

Martinus mengatakan, Lasro diperiksa terkait perannya dalam pengadaan UPS di sekolah-sekolah. Sebagai Kadisdik DKI, menurut Martinus, Lasro seharusnya mengetahui soal perencanaan hingga berlangsungnya proyek tersebut.

Selain Lasro, hari ini penyidik juga memanggil 10 orang lainnya yang diperiksa sebagai saksi kasus pengadaan UPS. Namun, dari 10 orang tersebut, baru empat saksi yang hadir di antaranya Panitia Pemeriksa Hasil Pekerjaan (PPHP) Rani Murani dari Suku Dinas Pendidikan Menengah Jakarta Barat, Kepala Sekolah SMA 112 Jakarta Barat Saryono, dan Kepala Suku Dinas Pendidikan Menengah Jakarta Barat Ibnu Hajar.

Sejak meningkatkan status kasus ini dari penyelidikan menjadi penyidikan, Polda Metro Jaya telah memanggil 21 orang. Namun, baru 12 orang yang memenuhi panggilan tersebut.

Sebelumnya, Gubernur DKI Jakarta Basuki Tjahaja Purnama mengungkapkan adanya pencantuman dana "siluman" pada APBD DKI Jakarta 2014. Salah satu dugaan dana siluman yakni pengadaan UPS pada 49 sekolah yang menghabiskan dana sekitar Rp5,8 miliar per sekolah.

Ahok kembali mengungkap dalam usulan anggaran 2015, pengadaan UPS kembali disisipkan dalam RAPBD 2015. Total usulan anggaran "siluman" dalam APBD 2015 mencapai Rp12,1 triliun. Di dalamnya, juga terdapat anggran pengadaan UPS. Kali ini, pengadaan UPS tidak hanya untuk sekolah, tapi juga kantor kelurahan dan kecamatan.

Sumber: http://news.metrotvnews.com/read/2015/03/11/369703/kasus-ups-polda-metro-periksa-mantankepala-dinas-pendidikan-dki

No 1: Bagaimana analisis Anda terkait kasus diatas jika dikaitkan dengan standar nasional pendidikan?

No 2 : factor apa saja yang dapat mempengaruhi kualitas pendidikan di suatu daerah? Jelaskan secara rinci! 
No 1: Bagaimana analisis Anda terkait kasus diatas jika dikaitkan dengan standar nasional pendidikan?

\section{Jawab:}

Kasus UPS, Polda Metro Periksa Mantan Kepala Dinas Pendidikan DKI, terkait dengan Standar Nasional Pendidikan (SNP).

Sebelum menganalisis kasus diatas, perlu dijelaskan mengenai Standar Nasional Pendidikan (SNP) serta fungsi atau peran Dinas Pendidikan yang dipimpin oleh Kepala Dinas.

Standar Nasional Pendidikan adalah kriteria minimal tentang sistem pendidikan di seluruh wilayah hukum Negara Kesatuan Republik Indonesia.

\section{Standar Nasional Pendidikan terdiri dari :}

- Standar Kompetensi Lulusan

- Standar Isi

- Standar Proses

- Standar Pendidikan dan Tenaga Kependidikan

- Standar Sarana dan Prasarana

- Standar Pengelolaan

- Standar Pembiayaan Pendidikan

- Standar Penilaian Pendidikan

\section{Fungsi dan Tujuan Standar :}

- Standar Nasional Pendidikan berfungsi sebagai dasar dalam perencanaan, pelaksanaan, dan pengawasan pendidikan dalam rangka mewujudkan pendidikan nasional yang bermutu 
- Standar Nasional Pendidikan bertujuan menjamin mutu pendidikan nasional dalam rangka mencerdaskan kehidupan bangsa dan membentuk watak serta peradaban bangsa yang bermartabat.

- Standar Nasional Pendidikan disempurnakan secara terencana, terarah, dan berkelanjutan sesuai dengan tuntutan perubahan kehidupan lokal, nasional, dan global.

Dalam mencapai Standar Nasional Pendidikan, Dinas Pendidikan yang dipimpin oleh Kepala Dinas memiliki peran sangat menentukan.

Peran (fungsi) Dinas Pendidikan

1. sebagai perumus kebijakan teknik di bidang pendidikan. Jadi semua yang berhubungan dengan kebijakan teknik pendidikan, akan diselenggarakan oleh Dinas Pendidikan.

2. sebagai penyelenggara umum di bidang pendidikan. Selain itu, Dinas Pendidikan juga berfungsi dalam mengatur penempatan guru yang bertugas, mulai dari pengangkatan Kepala Sekolah maupun untuk pengangkatan Pegawai Negeri Sipil

3. sebagai pembina, pelaksana, dan pengembangan tugas di bidang pendidikan. Dinas pendidikan berhak mengajar siswa dan mengangkat jabatan fungsional seperti Pengawas Pendidikan. Pengawas Pendidikan ini memiliki tugas untuk mengunjungi sekolah-sekolah dengan jadwal tertentu, yaitu dengan melakukan evaluasi dari semua yang ada di dalam sekolah, baik pendidik, sarana sekolah, serta semua yang berhubungan dengan proses belajar mengajar.

Dari uraian berita "Kasus UPS, Polda Metro Periksa Mantan Kepala Dinas Pendidikan DKI" yaitu Bapak Lasro Marbun hanya sebagai saksi dugaan korupsi 
pengadaan UPS saat ia masih menjabat sebagai Kepala Dinas Pendidikan DKI Jakarta. Jadi belum atau tidak terbukti melakukan korupsi pengadaan UPS. Oleh sebab itu, berita di atas jika dikaitkan kedudukannya sebagai kepala Dinas dengan Standar Nasional Pendidikan (SNP), Bapak Larso Marbun dapat dikatakan melakukan perannya sebagai Kepala Dinas.

Tetapi jika Bapak Larso Marbun ditetapkan sebagai tersangka, maka beliau tidak dapat menjalankan kepemimpinannya dengan baik dan amanah.

a. Berdasarkan peran (fungsi) Dinas Pendidikan yang dipimpin oleh Kepala Dinas tidak melaksanakan fungsinya sebagai perumus kebijakan teknik di bidang pendidikan. Jadi semua yang berhubungan dengan kebijakan teknik pendidikan, akan diselenggarakan oleh Dinas Pendidikan.

Seperti pendapat Kabid Humas Polda Metro Jaya Komisaris Besar Martinus Sitompul di Mapolda Metro Jaya, Rabu (11/3/2015) dalam uraian di atas Martinus mengatakan, " Lasro diperiksa terkait perannya dalam pengadaan UPS di sekolahsekolah. Sebagai Kadisdik DKI, menurut Martinus, Lasro seharusnya mengetahui soal perencanaan hingga berlangsungnya proyek tersebut”.

b. Kepala Dinas tidak melaksanakan fungsinya sebagai sebagai pembina, pelaksana, dan pengembangan tugas di bidang pendidikan, Dari uraian berita di atas, penyidik juga memanggil 10 orang lainnya yang diperiksa sebagai saksi kasus pengadaan UPS. Namun, dari 10 orang tersebut, baru empat saksi yang hadir di antaranya Panitia Pemeriksa Hasil Pekerjaan (PPHP) Rani Murani dari Suku Dinas Pendidikan Menengah Jakarta Barat, Kepala Sekolah SMA 112 Jakarta 
Barat Saryono, dan Kepala Suku Dinas Pendidikan Menengah Jakarta Barat Ibnu Hajar. 10 orang ini penyelenggara pendidikan dibawah Kepala Dinas Pendidikan.

\section{No 2 : factor apa saja yang dapat mempengaruhi kualitas pendidikan di suatu daerah? Jelaskan secara rinci!}

\section{Jawab:}

\section{Rendahnya Kualitas Sarana Fisik}

Untuk sarana fisik, banyak sekali lembaga pendidikan di Indonesia yang tidak layak untuk digunakan. Banyak pula sekolah dan perguruan tinggi kita yang gedungnya rusak, atau bahkan masih ada lembaga pendidikan yang belum memiliki gedungnya sendiri, kepemilikan dan penggunaan media belajar rendah, serta buku perpustakaan yang tidak lengkap. Sementara laboratorium tidak sesuai standar, pemakaian teknologi informasi tidak memadai dan sebagainya.

Nanang Fatah, seorang pakar pendidikan Universitas Pendidikan Indonesia (UPI) mengatakan sekitar $60 \%$ bangunan sekolah di Indonesia rusak berat. Di wilayah Jawa Barat, sekolah yang rusak mencapai $50 \%$.

Data Balitbang Depdiknas (2003) menyebutkan untuk satuan SD terdapat 146.052 lembaga yang menampung 25.918 .898 siswa serta memiliki 865.258 ruang kelas. Dari seluruh ruang kelas tersebut sebanyak 364.440 atau $42,12 \%$ berkondisi baik, 299.581 atau 34,62 \% mengalami kerusakan ringan, dan sebanyak 201.237 atau 23,26 \% mengalami kerusakan berat. keadaan yang serupa juga terjadi di SMP, MTs, SMA, dan SMK akan tetapi prosentasenya tidak sama.

\section{Rendahnya Kualitas Guru}


Keadaan guru di Indonesia juga memprihatinkan. Kebanyakan guru belum memiliki profesionalisme yang memadai untuk menjalankan tugasnya sebagaimana telah disebutkan dalam pasal 39 UU No. 20 / 2003 yaitu merencanakan pembelajaran, melakukan pembimbingan, melakukan perhatian, melakukan penelitian dan melakukan pengabdian masyarakat.

Walaupun guru atau pengajar bukanlah satu-satunya faktor penentu keberhasilan pendidikan tetapi pengajaran merupakan titik sentral pendidikan dan kualifikasi. Sebagai cermin kualitas, tenaga pengajar memiliki andil yang sangat besar pada kualitas pendidikan yang menjadi tanggung jawabnya.

\section{Rendahnya Kesejahteraan Guru}

Rendahnya kesejahteraan guru mempengaruhi peran dalam membuat kualitas pendidikan di Indonesia. Berdasarkan survei FGII (Federasi Gur Independen Indonesia) pada pertengahan tahun 2005, idealnya seorang guru menerima gaji bulanan sebesar Rp. 3.000.000,00. Sekarang pendapatan rata-rata guru perbulannya sebesar Rp. 1.500.000,00. Guru bantu Rp. 460.000,00 dan guru honorer di sekolah swasta rata-rata Rp. $10.000,00$ per jam.

Dengan pendapatan seperti itu, terang saja banyak guru-guru yang melakukan pekerjaan sampingan. Ada yang mengajar lagi di sekolah lain, memberi les pada sore hari, menjadi tukang ojek, pedagang mi rebus, pedagang buku/LKS, pedagang pulsa ponsel, dan sebagainya (Republika, 13 Juli 2005).

Selain itu kesenjangan guru swasta dan negeri menjadi masalah lain yang muncul. Di lingkungan pendidikan swasta, masalah kesejahteraan guru masih sulit mencapai taraf ideal. Sebanyak $70 \%$ dari 403 PTS di Jawa Barat dan Banten tidak 
sanggup untuk menyesuaikan kesejahteraan dosen sesuai dengan amanat UU Guru dan Dosen (Pikiran Rakyat, 9 Januari 2006).

Mengapa kesejahteraan guru menjadi hal yang berpengaruh terhadap kualitas pendidikan di Indonesia? Hal ini penting dan berpengaruh jika kesejahteraan seorang pengajar belum terpenuhi, kemungkinan besar akan sulit bagi pengajar untuk menyampaikan bahan ajar terhadap peserta didik dengan optimal karena bisa saja motivasi mereka untuk mentransfer ilmu menjadi berkurang. Dan konsentrasi pendidik pun lebih mengarah terhadap bagaimana memenuhi kebutuhannya sendiri.

\section{Rendahnya Prestasi Siswa}

Anak-anak Indonesia ternyata hanya mampu menguasai 30\% dari materi bacaan dan ternyata mereka sulit sekali menjawab soal-soal berbentuk uraian yang memerlukan penalaran. Hal ini mungkin karena mereka sangat terbiasa menghafal dan mengerjakan soal pilihan ganda.

Dengan keadaan-keadaan di atas, pencapaian prestasi siswa pun menjadi kurang memuaskan. Sebagai misal pencapaian prestasi fisika dan matematika siswa Indonesia di dunia internasional sangat rendah. Menurut Trends in Mathematics and Science Study (TIMSS) 2003 (2004), siswa Indonesia hanya berada di peringkat ke35 dari 44 negara dalam hal prestasi matematika dan berada di peringkat ke-37 dari 44 negara dalam hal prestasi sains.

Namun bukan berarti bahwa anak-anak di Indonesia bodoh. Pada dasarnya tidak ada anak yang bodoh. Yang ada adalah anak yang rajin dan yang kurang rajin.

Jika ditarik suatu garis hubungan, tinggi atau tidaknya motivasi belajar dari para siswa ini bisa juga disebabkan oleh faktor-faktor eksternal yang tidak akan diulas secara mendalam dalam makalah ini. 


\section{Mahalnya Biaya Pendidikan}

"Pendidikan bermutu itu mahal". Kalimat ini sering muncul untuk menjustifikasi mahalnya biaya pendidikan. Mahalnya biaya pendidikan dari taman kanak-kanak (TK) hingga Perguruan Tinggi (PT) membuat masyarakat yang kurang mampu tidak memilii pilihan lain selain tidak bersekolah.

Sebenarnya jika kita membandingkan dengan negara-negara lain untuk menempuh pendidikan di luar negeri jauh lebih mahal dibandingkan dengan biaya pendidikan kita. Namun mengapa rakyat masih menganggap biaya pendidikan di Indonesia tergolong sangat mahal? Tentu saja hal tersebut dapat terjadi mengingat keadaan ekonomi negara kita saat ini.

\section{Masalah Kurikulum}

Ada kekurangan yang dapat kita rangkum secara global dalam konteks pendidikan perihal kurikulum. Pertama, kurikulum pendidikan di Indonesia yang kurang menekankan pentingnya studi yang dalam dan berkelanjutan mengenai wawasan nusantara. Hal ini terbukti dengan kurangnya sorotan lembaga pendidikan terhadap alokasi waktu mata pelajaran khususnya Kewarganegaraan yang dalam realisasinya hanya mendapat sorotan selama $2 \mathrm{~s} / \mathrm{d} 2,5$ jam per minggunya.

Hal tersebut akan berdampak pada kurangnya jiwa nasionalisme dari peserta didik. Hal ini akan merugikan bangsa karena pada saat peserta didik memasuki dunia kerja. Orientasi utama mereka mungkin lebih mengarah terhadap materi dan bukannya member kontribusi terhadap negara.

Kedua, kurikulum pendidikan di Indonesia dari segi pengajaran kita yang kurang mengarahkan peserta didik untuk nantinya jika telah lulus menempuh 
pendidikan formal untuk menciptakan sesuatu. Hal ini akan membentuk kepribadian yang konsumtif.

\section{Kurangnya Pemerataan Kesempatan Pendidikan}

Kesempatan memperoleh pendidikan masih terbatas pada tingkat Sekolah Dasar. Data Balitbang Departemen Pendidikan Nasional dan Direktorat Jenderal Binbaga Departemen Agama tahun 2000 menunjukan Angka Partisipasi Murni (APM) untuk anak usia SD pada tahun 1999 mencapai 94,4\% (28,3 juta siswa). Pencapaian APM ini termasuk kategori tinggi. Angka Partisipasi Murni Pendidikan di SLTP masih rendah yaitu 54, $8 \%$ (9,4 juta siswa). Sementara itu layanan pendidikan usia dini masih sangat terbatas. Kegagalan pembinaan dalam usia dini nantinya tentu akan menghambat pengembangan sumber daya manusia secara keseluruhan. Oleh karena itu diperlukan kebijakan dan strategi pemerataan pendidikan yang tepat untuk mengatasi masalah ketidakmerataan tersebut.

\section{Rendahnya Relevansi Pendidikan dengan kebutuhan}

Hal tersebut dapat dilihat dari banyaknya lulusan yang menganggur. Data BAPPENAS (1996) yang dikumpulkan sejak tahun 1990 menunjukkan angka pengangguran terbuka yang dihadapi oleh lulusa SMU sebesar 25,47 \%, Diploma /

SO sebesar 27,5\% dan PT sebesar 36,6\%. Adanya ketidakserasian antara hasil pendidikan dan kebutuhan dunia kerja ini disebabkan kurikulum yang materinya kurang fungsional terhadap keterampilan yang dibutuhkan ketika peserta didik memasuki dunia kerja.

\section{Pembelajaran hanya pada buku paket}

Di indonesia telah berganti beberapa kurikulum dari KBK menjadi KTSP. Hampir setiap menteri mengganti kurikulum lama dengan kurikulum yang baru. 
Namun adakah yang berbeda dari kondisi pembelajaran di sekolah-sekolah? Tidak, karena pembelajaran di sekolah sejak zaman dulu masih memakai kurikulum buku paket. Sejak era 60-70an, pembelajaran di kelas tidak jauh berbeda dengan sebelumnya. Apapun kurikulumnya, guru hanya mengenal buku paket. Materi dalam buku paketlah yang menjadi acuan dan guru tidak mencari sumber referensi lain.

\section{Mengajar Satu Arah}

Metode pembelajaran yang menjadi favorit guru mungkin hanya satu, yaitu metode berceramah satu arah. Karena berceramah itu mudah dan ringan, tanpa modal, tanpa tenaga, tanpa persiapan yang rumit. Metode ceramah menjadi metode terbanyak yang dipakai guru karena memang hanya itulah metode yang benar-benar dikuasai sebagain besar guru. Pernahkah guru mengajak anak berkeliling sekolahnya untuk belajar ? Pernahkah guru membawa siswanya melakukan percobaan di alam lingkungan sekitar? Atau pernahkah guru membawa seorang ilmuwan langsung datang di kelas untuk menjelaskan profesinya?

\section{Aturan yang Mengikat}

Ini tentang Kurikulum Tingkat Satuan Pendidikan (KTSP). Sekolah seharusnya memiliki kurikulum sendiri sesuai dengan karakteristiknya.

\section{Guru tak Menanamkan Diskusi Dua Arah}

Lihatlah pembelajaran di ruang kelas. Sepertinya sudah diseragamkan. Anak duduk rapi, tangan dilipat di meja, mendengarkan guru menjelaskan. seolaholah Anak "Dipaksa" mendengar dan mendapatkan informasi sejak pagi sampai siang, belum lagi ada sekolah yang menerapkan Full Days. Anak diajarkan cara menyimak dan mendengarkan penjelasan guru, sementara kompetensi bertanya tak 
disentuh. Anak-anak dilatih sejak TK untuk diam saat guru menerangkan, untuk mendengarkan guru. Akibatnya Siswa tidak dilatih untuk bertanya. Siswa tidak dibiasakan bertanya, akibatnya siswa tidak berani bertanya. Selesai mengajar, guru meminta anak untuk bertanya. Heninglah suasana kelas. Yang bertanya biasanya anak-anak itu saja.

\section{Metode Pertanyaan Terbuka tak Dipakai}

Contoh negara yang menggunakan pertanyaan terbuka adalah Finlandia. Dalam setiap ujian, siwa boleh menjawab soal dengan membaca buku. Guru Indonesia belum siap menerapkan ini karena masih kesulitan membuat soal terbuka.

\section{Budaya Mencontek}

Siswa menyontek itu biasa terjadi. Tapi apakah kita tahu kalau "guru juga menyontek" ? Ini lebih parah. Lihatlah tes-tes yang diikuti guru, tes pegawai negeri yang diikuti guru, menyontek telah menjadi budaya sendiri.

\section{Efektifitas Pendidikan Di Indonesia}

Pendidikan yang efektif adalah suatu pendidikan yang memungkinkan peserta didik untuk dapat belajar dengan mudah, menyenangkan dan dapat tercapai tujuan sesuai dengan yang diharapkan. Dengan demikian, pendidik (dosen, guru, instruktur, dan trainer) dituntut untuk dapat meningkatkan keefektifan pembelajaran agar pembelajaran tersebut dapat berguna.

Efektifitas pendidikan di Indonesia sangat rendah. Setelah praktisi pendidikan melakukan penelitian dan survey ke lapangan, salah satu penyebabnya 
adalah tidak adanya tujuan pendidikan yang jelas sebelum kegiatan pembelajaran dilaksanakan. Hal ini menyebabkan peserta didik dan pendidik tidak tahu "goal" apa yang akan dihasilkan sehingga tidak mempunyai gambaran yang jelas dalam proses pendidikan. Jelas hal ini merupakan masalah terpenting jika kita menginginkan efektifitas pengajaran. Bagaimana mungkin tujuan akan tercapai jika kita tidak tahu apa tujuan kita.

Selama ini, banyak pendapat beranggapan bahwa pendidikan formal dinilai hanya menjadi formalitas saja untuk membentuk sumber daya manusia Indonesia. Tidak perduli bagaimana hasil pembelajaran formal tersebut, yang terpenting adalah telah melaksanakan pendidikan di jenjang yang tinggi dan dapat dianggap hebat oleh masyarakat. Anggapan seperti itu jugalah yang menyebabkan efektifitas pengajaran di Indonesia sangat rendah. Setiap orang mempunyai kelebihan dibidangnya masing-masing dan diharapkan dapat mengambil pendidikaan sesuai bakat dan minatnya bukan hanya ingin dianggap hebat oleh orang lain.

Dalam pendidikan di sekolah menengah misalnya, seseorang yang mempunyai kelebihan dibidang sosial dan dipaksa mengikuti program studi IPA akan menghasilkan efektifitas pengajaran yang lebih rendah jika dibandingkan peserta didik yang mengikuti program studi yang sesuai dengan bakat dan minatnya. Hal-hal sepeti itulah yang banyak terjadi di Indonesia. Dan sayangnya masalah gengsi tidak kalah pentingnya dalam menyebabkan rendahnya efektifitas pendidikan di Indonesia.

\section{PERANAN PEMERINTAH DALAM PENINGKATAN KUALITAS PENDIDIKAN DI INDONESIA}


Dari uraian tentang beberapa permasalahan pendidikan secara khusus di atas, pemerintah telah memberikan beberapa solusi untuk mengatasinya. Solusi tersebut, yang akan saya paparkan, ada yang telah terlaksana dan ada yang dalam proses karena memiliki jangka waktu berkala atau menjadi sebuah terapan setiap tahunnya. Solusi permasalahan tersebut adalah :

\section{Rendahnya Kualitas Sarana Fisik}

Pemerintah setiap tahunnya telah berusaha meningkatkan anggaran untuk pendidikan. Dan tentu saja sasarannya adalah agar seluruh masyarakat Indonesia bisa menikmati pendidikan yang bermutu dengan kondisi yang mendukung.

\section{Rendahnya Kualitas Guru}

Pemerintah mulai aktif dalam pemberian bekal, penyuluhan, lokakarya, dan sebagainya untuk meningkatkan kualitas pendidik di Indonesia. Terbukti saat ini seluruh Pegawai Negeri Sipil yang telah atau sedang mengajar, harus bergelar S1. Ini berarti, mau tidak mau bagi pengajar yang bergelar diploma harus menempuh pendidikan lanjutan untuk mendapat gelar Sarjana dan secara otomatis, mereka akan mendapatkan ilmu yang lebih pula. Dan diharapkan dengan kebijakan ini, pengajar di Indonesia dapat lebih meningkat kualitasnya.

\section{Randahnya Kesejahteraan Guru}

Rendahnya kesejahteraan guru sangat berkaitan dengan rendahnya kualitas guru dan kualitas pendidikan di Indonesia. Pemerintah sendiri telah menjalankan program Sertifikasi Guru yang sasarannya adalah semua Pegawai Negeri Sipil lebih khususnya adalah guru. Sertifikasi ini tidak dilaksanakan dengan serentak namun 
secara berkala dengan maksud, guru yang pengangkatannya lebih lama mendapat giliran terlebih dahulu dan selanjutnya guru-guru lainnya.

Dengan diadakannya sertifikasi ini, kesejahteraan guru pun akan meningkat sekaligus kualitas mereka juga akan meningkat. Karena, bagi guru yang tidak lulus sertifikasi, akan diberikat diklat atau semacam pelatihan yang pada akhirnya akan lulus juga. Namun, bukan hanya sekedar lulus, tujuan dari diklat itu adalah memberikan bekal agar kualitas guru saat kembali mengajar semakin meningkat. Dengan demikian, dua masalah yang ada dapat diberikan suatu solusi sekaligus.

\section{Rendahnya Prestasi Siswa}

Untuk meningkatkan motivasi siswa agar prestasi mereka meningkat, pemerintah setiap tahunnya selalu meningkatkan standar kelulusan minimal yang harus dicapai siswa. Hal ini dimaksudkan agar dengan naiknya standar kelulusan minimal siswa dapat lebih rajin dan lebih giat lagi belajar untuk mencapai standar tersebut.

\section{Mahalnya Biaya Pendidikan}

Untuk masalah ini, pemerintah telah mencanangkan program BOS (Bantuan Operasinal Siswa). Dengan BOS, pendidikan di Indonesia dapat dinikmati oleh semua kalangan (walaupun masih sampai jenjang SMP). Namun, saat ini juga telah banyak lembaga-lembaga yang memberikan beasiswa untuk siswa yang berprestasi maupun untuk siswa yang tidak mampu. Dengan adanya hal itu, kerja sama antara pemerintah dengan pihak-pihak yang menyelenggarakan hal tersebut dapat meningkatkan motivasi belajar dari siswa itu sendiri. Selain itu, adanya program ini 
tentu saja bukti realisasi dan keseriusan pemerintah agar seluruh rakyatnya dapat menikmati pendidikan.

\section{Masalah Kurikulum}

Untuk mengatasi masalah kurikulum yang ada, pemerintah telah berusaha untuk mengganti kurikulum yang dianggap kurang tepat dan kurang efisien dengan kurikulum baru yang dianggap lebih efisien. Contohnya pada tahun 2004, pemerintah telah mengganti kurikulum 1994 dengan Kurikulum Berbasis Kompetensi, dan saat ini kurikulum sudah berganti menjadi KTSP (Kurikulum Satuan Tingkat Pendidikan).

Dari uraian sederhana di atas cukup memberikan bukti bahwa pemerintah tidak pernah main-main dalam urusan pendidikan di Indonesia terutama untuk pengingkatan kualitas pendidikannya. Walaupun pada kenyataannya kebijakan-kebijakan di atas memunculkan pro dan kontra di berbagai kalangan. Namun pemerintah terus berusaha dengan menerapkan upaya-upaya untuk meningkatkan kualitas pendidikan di Indonesia.

\section{PERAN PEMERINTAH DALAM MENINGKATKAN MUTU PENDIDIKAN MENURUT UUD}

Pembukaan Undang-Undang Dasar Negara Republik Indonesia tahun 1945 (UUD 1945) mengamanatkan bahwa Pemerintah Negara Indonesia harus melindungi segenap bangsa Indonesia dan seluruh tumpah darah Indonesia dan untuk memajukan kesejahteraan umum, mencerdaskan kehidupan bangsa, dan ikut melaksanakan ketertiban dunia yang berdasarkan kemerdekaan, perdamaian abadi dan keadilan sosial. Dengan demikian, Pemerintah diwajibkan untuk mengusahakan dan menyelenggarakan satu sistem pendidikan nasional bagi seluruh warga negara Indonesia. 
Sistem pendidikan nasional dimaksud harus mampu menjamin pemerataan kesempatan dan peningkatan mutu pendidikan, terutama bagi anak-anak, generasi penerus keberlangsungan dan kejayaan Bangsa dan Negara Kesatuan Republik Indonesia (NKRI). Upaya yang telah dilakukan oleh pemerintah melalui berbagai paket program pendidikan sebagai impelementasi penggunaan anggaran pendidikan $20 \%$ dari APBN, utamanya di daerah-daerah tertinggal masih sangat minim dibandingkan dengan kebutuhan masyarakat. Program-program yang dibuat oleh pemerintah seringkali hanya program tambal sulam (incremental) dan tidak berkelanjutan (sustainable). Banyaknya sekolah, utamanya sekolah dasar yang dalam kondisi rusak berat dan hanya direhabilitasi melalui Biaya Orientasi Sekolah (BOS) dan berbagai paket program sejenis lainnya, tidaklah menjadikan sarana dan prasarana pendidikan tersebut menjadi lebih baik. Banyaknya sekolah dasar yang rusak tersebut menyebabkan anakanak usia pendidikan dasar tidak merasa nyaman dalam proses pembelajaran. Padahal untuk anak-anak usai tersebut, dukungan sarana dan prasarana yang memadai amat dibutuhkan guna menunjang keberhasilan pendidikannya. Pemerintah memegang peranan penting dalam meningkatkan kualitas pendidikan anak-anak Indonesia, utamanya mulai dari ketersediaan sarana dan prasarana minimal berupa gedung sekolah yang layak, hingga sampai pada ketersediaan berbagai fasilitas pendukung pendidikan lainnya.

Bagi sekolah-sekolah yang berada di perkotaan, sekolah yang rusak berat dan masih belum direhabilitasi sangat banyak ditemui, apalagi di daerah-daerah terpencil di Indonesia. Dengan kata lain, sekolah-sekolah diperkotaan saja kondisinya masih demikian, apalagi di pelosok Indonesia. Selain ketersediaan sarana dan prasarana fisik dan berbagai fasilitas pendukung pendidikan lainnya yang masih terbatas dan 
belum menjangkau seluruh wilayah NKRI, kurikulum pendidikan dasar pun menjadi permasalahan. Kurikulum yang seringkali berubah seiring dengan pergantian rezim pemerintahan menyebabkan anak-anak usia sekolah dasar menjadi korbannya. Anakanak usia sekolah dasar merupakan anak-anak yang mind set berfikirnya belum terbentuk, anak-anak tersebut masih dalam tahap amati dan tiru, belum sampai tahap modifikasi. Selain itu, beban kurikulum yang berat menyebabkan anak-anak kehilangan kreativitasnya karena hanya dibebani dengan mata pelajaran yang terkonsep dan berpola baku secara permanen. Artinya, apa yang di dapat di sekolah, itulah yang ada pada dirinya, tanpa kecuali.

Pemerintah harus menyadari bahwasannya anak-anak merupakan investasi masa depan sebuah bangsa. Merekalah yang kelak akan mengisi ruang-ruang proses berbangsa dan bernegara. Wajar saja ketika banyak orang menyerukan bahwa anak adalah bibit-bibit atau tunas yang harus diperhatikan dan dirawat dengan baik. Merekalah pewaris masa depan, tulang punggung dan harapan bangsa dan negara ada di pundak mereka. Namun, harapan itu ternyata masih membentur tembok yang sangat besar. Ternyata masih banyak di temukan anak-anak kurang mampu harus berhenti sekolah karena tidak memiliki biaya. Sering dijumpai bahwa anak-anak Indonesia harus dipaksa mengemis demi menghidupi keluarga, melakukan tindak kriminal dan terlantar karena ketimpangan ekonomi. Tidak jarang pula anak-anak seringkali menghadapi bentuk-bentuk kekerasan baik fisik maupun non fisik. Padahal, anak-anak Indonesia harusnya berada di rumah, belajar dengan baik dan menikmati tugas-tugas bagi tumbuh kembang diri mereka. Disinilah peran pemerintah harus ditingkatkan dalam rangka peningkatan pendidikan anak-anak Indonesia. Pendidikan Karakter merupakan proses pemberian tuntunan peserta/anak 
didik agar menjadi manusia seutuhnya yang berkarakter dalam dimensi hati, pikir, raga, serta rasa dan karsa. Peserta didik diharapkan memiliki karakter yang baik meliputi kejujuran, tanggung jawab, cerdas, bersih dan sehat, peduli, dan kreatif. Pemerintah melalui Kemendiknas meluncurkan sebuah program pendidikan, yang dikenal dengan Pendidikan Karakter. Dominasi ranah kognitif dan psikomotorik harus dikurangi, ranah afektif sudah seharusnya menjadi fokus utama. Sehingga terbentuklah manusia-manusia yang berkarakter luhung, berbudi pekerti tinggi. Manusia-manusia seperti inilah yang diharapkan mampu membawa bangsa Indonesia menjadi jauh lebih baik, menjadikan Indonesia sebagai bangsa yang berbudaya tinggi. Pendidikan karakter dibutuhkan untuk mencegah setiap perbuatan-perbuatan yang tidak baik yang dapat merusak pendidikan di Indonesia. Oleh karena itu, semua peran sangat dibutuhkan untuk memajukan sistem pendidikan di Indonesia agar pendidikan di Indonesia mengalami pemerataan, peningkatan dan perubahan yang signifikan. Pendidikan Karakter bertujuan untuk memberikan pengetahuan tentang hal yang baik dan buruk, kemudian membuat hal yang baik menjadi suatu kebiasaan.

Budaya ini harus dipelihara agar pendidikan di Indonesia berkembang dan bisa menjadi daya saing bagi pendidikan lainnya secara global. Pendidikan memegang peranan yang sangat penting dalam proses peningkatan kualitas sumber daya manusia dan merupakan suatu proses yang terintegrasi dengan proses peningkatan kualitas sumber daya manusia itu sendiri. Menyadari pentingnya proses peningkatan kualitas sumber daya manusia, maka Pemerintah telah berupaya mewujudkan amanat tersebut melalui berbagai usaha pembangunan pendidikan yang lebih berkualitas melalui pengembangan dan perbaikan kurikulum dan sistem evaluasi, perbaikan sarana pendidikan, pengembangan dan pengadaan materi ajar, serta pelatihan bagi guru dan 
tenaga kependidikan lainnya. Tetapi kenyataan belum cukup dalam meningkatkan kualitas pendidikan.

Sumber:

Manurung, T.M.S., 2017. Pengaruh Motivasi dan Perilaku Belajar Terhadap Prestasi Akademik Mahasiswa. JAS-PT Jurnal Analisis Sistem Pendidikan Tinggi, 1(1), pp.17-26.

Cahyana, R. and Sagala, I., 2017. Model Sistem Perubahan dalam Lingkup Program Sarjana. JAS-PT Jurnal Analisis Sistem Pendidikan Tinggi, 1(1), pp.47-52.

https://www.websitependidikan.com/2016/03/tugas-dan-fungsi-dinas-pendidikan.html https://www.websitependidikan.com/2016/03/tugas-dan-fungsi-dinas-pendidikan.html https:/goenable.wordpress.com/2012/01/08/tentang-permendiknas-no-19-tahun-2007/ https://dinaspendidikankotagorontalo.wordpress.com/profil/tupoksi/ http://mynewblogpendidikandasar.blogspot.com/2016/07/faktor-yang-mempengaruhikualitas.html

http://bacaankitadansemua.blogspot.com/2014/08/faktor-yang-mempengaruhipendidikan.html

Sastra, H., 2018. Minat Berinvestasi Mahasiswa dan Kualitas Pelayanan Gerai Bursa Efek Indonesia STIE Kesatuan Bogor. JAS-PT Jurnal Analisis Sistem Pendidikan Tinggi, 2(1), pp.1-12.

Astuti, S.P. and Utami, D.E., 2018. Pengembangan Kualitas Perguruan Tinggi Islam Berdasarkan Keinginan dan Kebutuhan Stakeholder. JAS-PT (Jurnal Analisis Sistem Pendidikan Tinggi Indonesia), 2(2), pp.71-82.

Ariffin, M., Suharmiati, S. and Amwilla, A.Y., 2018. Persepsi Mahasiswa Atas Kualitas Pelayanan Laboratorium Bank Mini STIE Kesatuan dan Implikasinya Terhadap Kepuasan Mahasiswa. JAS-PT Jurnal Analisis Sistem Pendidikan Tinggi, 2(1), pp.13-18.

Lazarus, D., 2018. Student Self-Responsibility in the Indonesian Distance Education System. JAS-PT Jurnal Analisis Sistem Pendidikan Tinggi, 1(2), pp.69-78.

Iriyadi, I., Pamungkas, B. and Gunawan, L.G., 2015. Sistem Informasi Akuntansi Dalam Kaitannya Dengan Laporan Biaya Produksi Pada Perusahaan CV Surya Pratama Gemilang. Jurnal Ilmiah Akuntansi Kesatuan, 3(3).

Pamungkas, B., 2008. Akuntabilitas Instansi Pemerintah, Survei Pada Pemerintah Dati II DI Yogyakarta.

Purba, J.H.V. and Munawar, A., 2008. Kajian Dampak Pelatihan terhadap Kinerja Karyawan. Jurnal Ilmiah Ranggagading (JIR), 8(2), pp.95-102. 